\title{
Pengaruh Kepercayaan Konsumen terhadap Loyalitas Pelanggan dalam Penggunaan Sistem Pembayaran Online (Survei Pengguna Produk UniPin)
}

\author{
Rendy Rachman, Roswita Oktavianti \\ rendytju@gmail.com,roswitao@fikom.untar.ac.id
}

Fakultas Ilmu Komunikasi Universitas Tarumanagara

\begin{abstract}
Consumer trust in a brand can lead to consumer loyalty to that brand. Consumer trust is very important in a company because it will increase customer loyalty to the company itself. A high trust from consumers can create customer loyalty. Customer loyalty is the behavior to make repeated purchases and to build customer loyalty to a product or service produced by the company. This study aims to measure the effect of consumer trust on customer loyalty in using online payment system services. This research uses a quantitative approach with a survey method. Primary data was collected through distributing questionnaires to 90 respondents, namely the people of West Jakarta who have used UniPin as a payment service to buy credit or online game currency. Data analysis used the Statistical Package for the Social Sciences with the SPSS for Windows 22 application. Based on the results of the study, it is known that there is a positive influence between consumer trust and customer loyalty from Unipin companies. Consumer trust has an effect of $67.4 \%$ on customer loyalty. If consumer confidence increases, customer loyalty will also increase. Conversely, if consumer confidence decreases, customer loyalty will also decline.
\end{abstract}

Keywords: consumer trust, customer loyalty, online payment system

\begin{abstract}
Abstrak
Kepercayaan konsumen terhadap suatu merek dapat menimbulkan kesetiaan konsumen pada merek tersebut. Kepercayaan konsumen sangat penting dalam suatu perusahaan karena akan meningkatkan loyalitas pelanggan terhadap perusahaan itu sendiri. Suatu kepercayaan dari konsumen yang tinggi dapat menciptakan loyalitas pelanggan. Loyalitas pelanggan merupakan perilaku untuk melakukan pembelian secara berulang dan untuk membangun kesetiaan pelanggan terhadap suatu produk atau jasa yang dihasilkan oleh perusahaan. Penelitian ini bertujuan untuk mengukur pengaruh kepercayaan konsumen terhadap loyalitas pelanggan dalam menggunakan jasa sistem pembayaran online. Penelitian ini menggunakan pendekatan kuantitatif dengan metode survei. Data primer dikumpulkan melalui penyebaran kuesioner kepada 90 responden yaitu masyarakat daerah Jakarta Barat yang pernah menggunakan UniPin sebagai layanan pembayaran untuk membeli credit atau mata uang game online. Analisis data menggunakan Statistical Package for the Social Sciences dengan aplikasi SPSS for windows 22. Berdasarkan hasil penelitian, diketahui bahwa terdapat pengaruh positif antara kepercayaan konsumen terhadap loyalitas pelanggan dari perusahaan Unipin. Kepercayaan konsumen memiliki pengaruh sebesar $67,4 \%$ terhadap loyalitas pelanggan. Apabila kepercayaan konsumen meningkat maka loyalitas pelanggan juga akan meningkat. Sebaliknya, apabila kepercayaan konsumen menurun maka loyalitas pelanggan juga akan ikut menurun.
\end{abstract}

Kata kunci: kepercayaan konsumen, loyalitas pelanggan, sistem pembayaran online 
Rendy Rachman, Roswita Oktavianti: Pengaruh Kepercayaan Konsumen Terhadap Loyalitas Pelanggan Dalam Penggunaan Sistem Pembayaran Online (Survei Terhadap Pengguna Produk UniPin)

\section{Pendahuluan}

Perkembangan zaman mempengaruhi berbagai segi kehidupan manusia salah satunya tergantinya cara bermain tradisional dengan cara bermain modern. Satusatunya permainan zaman modern saat ini yang banyak digemari yaitu game online. Game online adalah permainan yang dioperasikan melalui koneksi internet. Game online adalah permainan komputer yang dimainkan banyak orang melalui jaringan internet (Kurniawan, 2017).

Dalam permainan game online terdapat mata uang elektronik yang dapat digunakan sebagai alat pembayaran. Cara untuk mendapatkan mata uang tersebut adalah dengan cara membelinya melalui platform atau website dari game itu sendiri. Ada banyak situs maupun platform yang menjual mata uang game online, salah satunya adalah PT. 24JamOnline atau yang lebih dikenal dengan UniPin. UniPin merupakan perusahaan startup pembayaran asal Indonesia yang memiliki kegunaan untuk mempermudah sistem jual-beli untuk game online. UniPin selalu melakukan kerja sama dengan banyak publisher game online untuk memungkinkan para gamer semakin mudah dalam melakukan pembelian dan pembayaran kredit atau mata uang elektronik dalam game tersebut.

Kepercayaan konsumen adalah kesediaan konsumen untuk mempercayai suatu merek yang akan menimbulkan hasil yang positif kepada konsumen sehingga dapat menimbulkan kesetiaan kepada suatu merek (Ferrinadewi, 2008). Menurut Lau dan Lee, karakteristik merek, karakteristik perusahaan, dan karakteristik hubungan pelanggan dengan merek merupakan suatu prediktor penting dalam kepercayaan pelanggan kepada merek, yang pada akhirnya dapat mengarah kepada loyalitas pelanggan dalam merek tersebut (Tjahyadi, 2006:66). UniPin dalam meningkatkan karakteristik perusahaannya, mereka selalu menjanjikan bahwa mereka adalah platform yang aman dalam menjembatani gamer dengan publisher game online dalam transaksi.

Loyalitas pelanggan adalah perilaku seseorang saat melakukan pembelian secara berulang - ulang dan juga membangun kesetiaan pelanggan kepada suatu produk dan jasa yang dihasilkan oleh badan usaha untuk membentuk waktu yang cukup lama melalui suatu proses pembelian yang dilakukan secara berulang - ulang (Rivai \& Wahyudi, 2017). Pelanggan yang loyal adalah konsumen yang puas dan akan meneruskan hubungan pembelian, hingga loyalitas konsumen juga merupakan suatu ukuran kedekatan konsumen kepada sebuah merek terebut, jika konsumen menyukai sebuah merek, merek tersebut menjadi top of mind jika teringat suatu kategori produk, komitmen yang terdalam akan memaksa preferensi pilihan dan bertujuan melakukan pembelian, sehingga seketika berbelanja akan lebih mudah (Hasan, 2013). Berdasarkan penjelasan latar belakang di atas, penulis tertarik untuk mengetahui apakah ada hubungan dan pengaruh antara kepercayaan konsumen terhadap loyalitas pelanggan dalam penggunaan sistem pembayaran online.

\section{Metode Penelitian}

Dalam penelitian ini peneliti memilih pendekatan kuantitatif dengan metode survei. Metode survei adalah penelitian yang dilakukan untuk mengumpulkan data atau informasi yang dilakukan dengan cara mengajukan daftar pertanyaan atau pernyataan kepada responden. Penggalian data dapat dilakukan melalui kuesioner dan 
wawancara (Sujarweni, 2014:8). Populasi adalah generalisasi yang mempunyai kualitas dan karakteristik tertentu yang ditetapkan oleh peneliti (Sugiyono, 2017:80).

Populasi yang peneliti gunakan dalam penelitian ini adalah masyarakat Jakarta Barat. Sampel adalah bagian dari sejumlah yang dimiliki oleh populasi, bila populasi besar peneliti dapat menggunakan sampel yang diambil dari populasi itu sendiri (Sujarweni, 2019:65). Untuk menentukan jumlah sampel minimum dalam penelitian ini, penulis menggunakan teori Roscoe dengan cara jumlah indikator dikali 5. Dalam penelitian ini, penulis menyebarkan kuesioner kepada 90 responden masyarakat daerah Jakarta Barat yang pernah menggunakan UniPin sebagai layanan pembayaran untuk membeli credit atau mata uang game online mereka.

Penelitian ini menggunakan teknik nonprobability sampling. Nonprobability sampling adalah teknik pengambilan sampel yang tidak memberikan peluang atau kesempatan yang sama untuk setiap anggota populasi untuk dipilih sebagai sampel penelitian (Sujarweni, 2019:71). Dalam penelitian ini, peneliti menggunakan teknik nonprobability sampling dengan pendekatan purposive sampling. Dalam penelitian ini diukur menggunakan skala likert dengan bantuan software SPSS ver. 22 untuk menguji validitas, reabilitas, dan hipotesis.

\section{Hasil Penelitian dan Diskusi}

Dalam penelitian ini, peneliti menyebarkan kuesioner kepada sebanyak 90 responden dan mendapatkan data berupa jenis kelamin, sebanyak 52 responden $(57,8 \%)$ berjenis kelamin laki-laki dan sebanyak 38 responden $(42,2 \%)$ berjenis kelamin perempuan. Sedangkan secara usia, responden di dominasi pada usia $22-26$ tahun sebanyak 58 responden $(64,4 \%)$, kemudian $17-21$ tahun sebanyak 28 responden $(31,1 \%)$, lalu $27-30$ tahun sebanyak 4 responden $(4,4 \%)$. Setelah melakukan uji validitas dengan menggunakan aplikasi SPSS for windows ver 22, maka berikut adalah hasil dari uji validitas.

Tabel 1. Uji Validitas

\begin{tabular}{|c|c|c|c|}
\hline \\
\hline Variabel & Butir Indikator & $\begin{array}{c}\text { Corrected Item } \\
\text { Total Correlation }\end{array}$ & Keterangan \\
\hline \multirow{11}{*}{$\begin{array}{c}\text { Kepercayaan } \\
\text { Konsumen } \\
\text { (X) }\end{array}$} & KK 1 & 0,823 & Valid \\
\hline & KK 2 & 0,784 & Valid \\
\hline & KK 3 & 0,777 & Valid \\
\hline & KK 4 & 0,636 & Valid \\
\hline & KK 5 & 0,739 & Valid \\
\hline & KK 6 & 0,682 & Valid \\
\hline & KK 7 & 0,738 & Valid \\
\hline & KK 8 & 0,766 & Valid \\
\hline & KK 9 & 0,769 & Valid \\
\hline & KK 10 & 0,777 & Valid \\
\hline & KK 11 & 0,748 & Valid \\
\hline \multirow{6}{*}{$\begin{array}{l}\text { Loyalitas } \\
\text { Pelanggan } \\
\text { (Y) }\end{array}$} & LP 1 & 0,711 & Valid \\
\hline & LP 2 & 0,767 & Valid \\
\hline & LP 3 & 0,748 & Valid \\
\hline & LP 4 & 0,730 & Valid \\
\hline & LP 5 & 0,717 & Valid \\
\hline & LP 6 & 0,791 & Valid \\
\hline
\end{tabular}




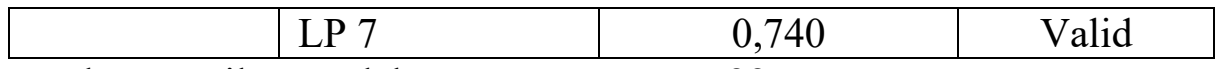

Sumber: Hasil Pengolahan Data SPSS Ver 22

Tabel 1, menunjukkan bahwa butir-butir indikator pernyataan dari seluruh variabel dinyatakan valid seluruhnya karena memiliki angka korelasi di atas 0,2.

Tabel 2. Uji Reliabilitas

\begin{tabular}{|c|c|c|}
\hline Variabel & $\begin{array}{c}\text { Nilai Cronbach's } \\
\text { Alpha }\end{array}$ & Keterangan \\
\hline Kepercayaan Konsumen (X) & 0,942 & Reliabel \\
\hline Loyalitas Pelanggan (Y) & 0,915 & Reliabel \\
\hline
\end{tabular}

Sumber: Hasil Pengolahan Data SPSS Ver. 22

Tabel 2, menunjukkan bahwa setiap pernyataan dalam kuisoner dikatakan reliabel karena memiliki nilai Cronbach's Alpha di atas 0,6.

Tabel 3. Uji Normalitas One-Sample Kolmogorov-Smirnov Test

\begin{tabular}{|l|l|r|r|}
\hline \multicolumn{2}{|l|}{} & \multicolumn{1}{c|}{ TX } & \multicolumn{1}{c|}{ TY } \\
\hline N & 90 & 90 \\
\hline \multirow{2}{*}{ Normal Parameters ${ }^{\mathrm{a}, \mathrm{b}}$} & Mean & 44.21 & 27.02 \\
\cline { 2 - 5 } & Std. Deviation & 5.978 & 4.767 \\
\hline \multirow{3}{*}{ Most Extreme Differences } & Absolute & .204 & .203 \\
\cline { 2 - 5 } & Positive & .127 & .126 \\
\cline { 2 - 5 } & Negative & -.204 & -.203 \\
\hline \multicolumn{2}{|l|}{ Test Statistic } & .204 & .203 \\
\hline Asymp. Sig. (2-tailed) & $.000^{\mathrm{c}}$ & $.000^{\mathrm{c}}$ \\
\hline Monte Carlo Sig. (2-tailed) & Sig. & $.080^{\mathrm{d}}$ & $.092^{\mathrm{d}}$ \\
\cline { 2 - 5 } & $99 \%$ Confidence Interval & .006 & .006 \\
\hline
\end{tabular}

Sumber: Hasil Pengolahan Data SPSS Versi 22.0

Dalam penelitian ini, peneliti menggunakan uji One Sample Kolmogorov Smirnov yang ada pada aplikasi SPSS Ver 22. Hasil analisis pada tabel 3 menunjukkan bahwa ada nilai signifikansi sebesar 0,080 untuk variabel $\mathrm{X}$ dan 0,092 untuk variabel Y. Hasil tersebut menyatakan bahwa distribusi data berdistribusi secara normal karena nilai signifikansi $\mathrm{X}$ dan $\mathrm{Y}>0,05$.

Tabel 4. Hasil Uji Koefisien Korelasi

\begin{tabular}{|c|c|c|c|c|}
\hline Model & $\mathrm{R}$ & $\mathrm{R}$ Square & $\begin{array}{c}\text { Adjusted R } \\
\text { Square }\end{array}$ & $\begin{array}{c}\text { Std. Error of } \\
\text { the Estimate }\end{array}$ \\
\hline 1 & $.821 \mathrm{a}$ & .674 & .670 & 3,077 \\
\hline
\end{tabular}

Sumber: Hasil Pengolahan Data SPSS Ver 22

Dari hasil perhitungan Tabel 4, diketahui bahwa nilai koefisien korelasi $\mathrm{R}$ sebesar 0,821 yang berada di antara interval $0,80-0,100$ artinya kepercayaan konsumen mempunyai hubungan yang sangat tinggi terhadap loyalitas pelanggan. 
Tabel 5. Hasil Uji Determinasi

\begin{tabular}{|c|c|c|c|c|}
\hline Model & $\mathrm{R}$ & $\mathrm{R}$ Square & $\begin{array}{c}\text { Adjusted R } \\
\text { Square }\end{array}$ & $\begin{array}{c}\text { Std. Error of } \\
\text { the Estimate }\end{array}$ \\
\hline 1 & $.821 \mathrm{a}$ & .674 & .670 & 3,077 \\
\hline
\end{tabular}

Sumber: Hasil Pengolahan Data SPSS Ver 22

Dari hasil perhitungan tabel 5, diketahui bahwa nilai koefisien determinasi pada tabel R Square sebesar 0,674 menunjukkan bahwa 67,4\% loyalitas pelanggan dipengaruhi oleh kepercayaan konsumen sementara sisanya 32,6\% (100\%-67,4\%) dipengaruhi oleh faktor lain.

Tabel 6. Hasil Uji Regresi Linear Sederhana

\begin{tabular}{|c|c|c|c|c|c|c|}
\hline \multicolumn{2}{|c|}{} & \multicolumn{2}{|c|}{$\begin{array}{c}\text { Unstandardized } \\
\text { Coefficients }\end{array}$} & $\begin{array}{c}\text { Standardized } \\
\text { Coefficients }\end{array}$ & t & Sig. \\
\cline { 3 - 7 } \multicolumn{2}{c|}{ Model } & B & Std. Error & Beta & & \\
\hline 1 & (Constant) & 2,005 & 1,868 & & 1,073 & 0,286 \\
\cline { 2 - 7 } & $\begin{array}{c}\text { Kepercayaan } \\
\text { Konsumen }\end{array}$ & 0,577 & 0,043 & 0,821 & 13,482 & 0,000 \\
\hline
\end{tabular}

Sumber: Hasil Pengolahan Data SPSS Ver 22

Dengan keterangan $\mathrm{Y}=$ Loyalitas pelanggan dan $\mathrm{X}=$ Kepercayaan konsumen. Berdasarkan persamaan regresi linear pada tabel 5, dapat diuraikan sebagai berikut:

1. Nilai Y (Loyalitas pelanggan) akan tetap sebesar 2,005 konstanta jika nilai $X$ (Kepercayaan Konsumen) tidak mengalami perubahan, baik peningkatan maupun penurunan.

2. Jika nilai $X$ (Kepercayaan Konsumen) mengalami peningkatan nilai sebesar 1 satuan, maka nilai Y (Loyalitas Pelanggan) akan mengalami peningkatan sebesar 0,577 menjadi 2,582 .

Tabel 7. Hasil Uji T

\begin{tabular}{|c|c|c|c|c|c|c|}
\hline \multicolumn{2}{|r|}{ Model } & \multicolumn{2}{|c|}{$\begin{array}{c}\text { Unstandardized } \\
\text { Coefficients }\end{array}$} & $\begin{array}{l}\text { Standardized } \\
\text { Coefficients }\end{array}$ & $\mathrm{t}$ & Sig. \\
\hline \multirow[t]{3}{*}{1} & (Constant) & $\mathrm{B}$ & Std. Error & Beta & & \\
\hline & \multirow{2}{*}{$\begin{array}{c}\text { Kepercayaan } \\
\text { Konsumen }\end{array}$} & 2,005 & 1,868 & & 1,073 & 0,286 \\
\hline & & 0,577 & 0,043 & 0,821 & 13,482 & 0,000 \\
\hline
\end{tabular}

Sumber: Hasil Pengolahan Data SPSS Ver 22

Tabel 7 menunjukkan dari hasil analisis data diketahui bahwa nilai $\mathrm{t}=13,482$ dan tingkat signifikansi $=0,000<0,05$. Karena nilai $\mathrm{p}<0,05$, maka $\mathrm{H}_{0}$ ditolak dan $\mathrm{Ha}$ diterima, yang berarti terdapat pengaruh positif kepercayaan konsumen terhadap loyalitas pelanggan.

\section{Kesimpulan}

Penelitian ini menyimpulkan bahwa terdapat hubungan antara kepercayaan konsumen terhadap loyalitas pelanggan dengan hubungan sangat tinggi. Berdasarkan hasil uji koefisien korelasi, diketahui bahwa nilai korelasi berada di antara interval 0,80 - 0,100 yang menunjukkan bahwa kepercayaan konsumen memiliki pengaruh 
yang sangat tinggi terhadap loyalitas pelanggan dan bersifat positif. Dengan demikian, semakin meningkatnya kepercayaan konsumen maka loyalitas pelanggan juga akan meningkat. Sebaliknya bila kepercayaan konsumen menurun maka loyalitas pelanggan juga akan menurun.

Berdasarkan kuesioner yang telah disebarkan, data pernyataan sebanyak 18 butir pernyataan dinyatakan valid, karena semua pernyataan yang telah disebarkan mendukung pernyataan bahwa ada pengaruh antara kepercayaan konsumen terhadap loyalitas pelanggan sebesar $67,4 \%$ sedangkan sisanya $32,4 \%$ dipengaruhi oleh faktor lain.

\section{Ucapan Terima Kasih}

Ucapan terima kasih diberikan Fakultas Ilmu Komunikasi Universitas Tarumanagara, responden, keluarga, teman-teman, dan semua pihak yang membantu peneliti dalam menyelesaikan penelitian ini.

\section{Daftar Pustaka}

Ferrinadewi, Erna. (2008). Merek dan Psikologi Konsumen. Cetakan ke - 1. Yogyakarta: Graha Ilmu.

Hasan, A. (2013). Marketing \& kasus-kasus pilihan. Yogyakarta: Center for Academic Publishing Service.

Kurniawan, D. E. (2017). Pengaruh Intensitas Bermain Game Online Terhadap Perilaku Prokrastinasi Akademik Pada Mahasiswa Bimbingan dan Konseling Universitas PGRI Yogyakarta. Jurnal Konseling Gusjigang. 3(1). Yogyakarta.

Rivai, A. R., \& Wahyudi, A. T. (2017). Pengaruh Persepsi Kualitas, Citra Merek, Persepsi Harga Terhadap Loyalitas Pelanggan Dengan Kepercayaan dan Kepuasan Pelanggan Sebagai Variabel Mediasi. Kalbisocio Jurnal Bisnis dan Komunikasi. 4(1). 29-37.

Sujarweni, Wiratna. (2019). Metodologi Penelitian. Yogyakarta: PT. Pustaka Baru.

Sugiyono. (2017). Metode Penelitian Kuantitatif, Kualitatif, dan R\&D. Bandung: Alfabeta.

Tjahyadi, R. A. (2006). Brand Trust dalam Konteks Loyalitas Merek: Peran Karakteristik Merek, Karakteristik Perusahaan, dan Karakteristik Hubungan Pelanggan - Merek. Jurnal Manajemen Universitas Kristen Maranatha. 6(1). $65-78$. 